\title{
Proximity and IPO Underpricing
}

\author{
Nielsson, Ulf; Wójcik, Dariusz
}

Document Version

Accepted author manuscript

Published in:

Journal of Corporate Finance

DOI:

10.1016/j.jcorpfin.2016.03.012

Publication date:

2016

License

CC BY-NC-ND

Citation for published version (APA):

Nielsson, U., \& Wójcik, D. (2016). Proximity and IPO Underpricing. Journal of Corporate Finance, 38, 92-105. https://doi.org/10.1016/j.jcorpfin.2016.03.012

Link to publication in CBS Research Portal

\section{General rights}

Copyright and moral rights for the publications made accessible in the public portal are retained by the authors and/or other copyright owners and it is a condition of accessing publications that users recognise and abide by the legal requirements associated with these rights.

Take down policy

If you believe that this document breaches copyright please contact us (research.lib@cbs.dk) providing details, and we will remove access to the work immediately and investigate your claim. 


\section{Proximity and IPO Underpricing Ulf Nielsson and Dariusz Wójcik}

Journal article (Post print version)

Cite: Proximity and IPO Underpricing./Nielsson, Ulf; Wójcik, Dariusz. In: Journal of Corporate Finance, Vol. 38, 06.2016, p. 92-105.

DOl: 10.1016/j.jcorpfin.2016.03.012

Uploaded to Research@CBS: May 2016

(C) 2016. This manuscript version is made available under the CC-BY-NC-ND 4.0 license http://creativecommons.org/licenses/by-nc-nd/4.0/ 


\title{
Proximity and IPO Underpricing
}

\author{
Ulf Nielsson $^{\dagger}$ \\ Copenhagen Business School
}

\author{
Dariusz Wójcik \\ University of Oxford
}

March 2016

\begin{abstract}
This paper analyses the relationship between issuers' location and IPO underpricing in the U.S. from 1986-2014. Issuers headquartered in rural areas are associated with lower underpricing compared to urban firms. This finding is consistent with strong local bias in rural areas accompanied by superior local information, which associates with more accurate pricing and less money left on the table. The paper further finds that refined measures of local bias, such as proximity to finance professionals and density of financial expertise, correlate more with IPO underpricing than proximity to large cities.
\end{abstract}

\section{JEL classification: G10, G12, G30}

Keywords: IPO underpricing, proximity, local bias

Acknowledgements: We are grateful for valuable comments from Daniel Bradley, Isaac Hacamo, Yinghua He, Gur Huberman, Søren Hvidkjær, Demetris Koursaros, Tim Loughran, Desmond Marais, Massimo Massa, Tatyana Sokolyk, Herdis Steingrimsdottir and participants at various seminars and conferences. We also thank Nicholas Kreston for valuable research assistance. Ulf Nielsson gratefully acknowledges funding from the Danish Council for Independent Research.

\footnotetext{
† Corresponding author. Department of Finance, Copenhagen Business School, Solbjerg Plads 3, 2000 Frederiksberg, Denmark. E-mail address: un.fi@cbs.dk.
} 


\section{Introduction}

IPO underpricing is one of the best-documented empirical findings in finance. Underpricing, defined as the difference between the closing price on the first day of trading and the IPO offer price, averaged 18.8\% in the U.S. in the period 1980-2001 (Ritter and Welch, 2002). There are many theories of underpricing, ranging from those focused on information asymmetry to those emphasizing ownership and control. The relative contribution of these theories to explaining the empirical data on IPO underpricing remains far from conclusive (Ljungqvist, 2007). This paper offers a contribution to research on IPO underpricing by considering a recent stream of literature exploring the role of location and proximity in stock markets, documenting, e.g., local bias of investors (e.g., Coval and Moskowitz, 2001; Massa and Simonov, 2006; Gurun and Butler, 2012) and superior local information in rural areas (Bodnaruk, 2009). Thus far, there has been no crossover between the literatures on IPO underpricing and location.

Our conjecture is that companies in rural areas should experience less IPO underpricing because superior local information in such areas lowers uncertainty about the IPO value. More specifically, as rural investors exhibit a stronger local bias than urban investors (i.e., allocate a larger part of their stock portfolios to local companies), this gives them stronger incentives to acquire and take advantage of local information about rural issuers. As a consequence, a more intensive use of local information in the case of rural companies should result in lower uncertainty about IPO value, and thus - as verified in this paper - lower IPO underpricing.

This hypothesis is firmly founded on existing literature. The stronger local bias in rural areas has been documented by Bernile, Kumar and Sulaeman (2012), who use data on institutional investment in nearly 4,000 U.S. publicly traded companies in the period 19962008 showing that local stock ownership levels are higher in states with lower population 
density. In addition, they establish that local bias applies particularly to younger firms, which implies that local ownership is particularly relevant to firms at the time of their IPO, as they involve relatively young firms. Supporting evidence from Finland shows that investors who live outside Helsinki have a particularly strong bias towards holding local stocks (Grinblatt and Keloharju, 2001). This tendency of rural investors to invest heavily in local companies creates an incentive to acquire information on those companies, which the literature has found local investors particularly well equipped to do. For example, Coval and Moskowitz (2001) and Ivkovic and Weisbenner (2005) demonstrate the superior access of local investors to tacit, non-standardized information about issuers and show that superior returns realized by local investors are particularly high in rural areas of the U.S. Bodnaruk (2009) similarly shows that investors who move away from the Swedish countryside, thereby leaving behind close community ties, experience a greater loss in local information compared to those who move away from metropolitan areas. Thus, the stronger local bias in rural areas, accompanied by superior information, leads us to conjure that IPOs from rural areas require less underpricing to compensate investors for the uncertainty involved in an IPO.

While most existing studies on location in stock markets define rural and urban firms primarily on the basis of distance to large population centers (Loughran and Schultz, 2005; Loughran, 2007; John, Knyazeva and Knyazeva, 2011), we refine the measures of location and proximity by considering distance to areas that are either large or dense in financial expertise. The motivation for doing so is that these measures better capture areas with strong local bias, since local bias is particularly prevalent in areas with low investor sophistication (cf. Grinblatt and Keloharju, 2001; Bernile, Kumar, and Sulaeman, 2012). To capture the proximity of companies to sophisticated investors, we measure the distance between company location and the top ten places of financial employment. The amount of financial expertise most relevant to stock markets is captured with data on county-level employment in 
the securities industry, while its density is captured by dividing employment in the securities industry by the county's total population. In sum, building on existing research showing that local bias is relatively strong among households, less investment savvy institutions (Grinblatt and Keloharju, 2001), and in states with lower education levels (Bernile, Kumar, and Sulaeman, 2012), we expect local bias of investors to be strong - and hence underpricing to be low - in areas where stock market expertise is small and most sparse.

Empirical results are consistent with this local bias hypothesis. Our analysis covering U.S. IPOs for the period 1986-2014 shows that the IPOs of companies headquartered in areas with small and the least dense stock market expertise are associated with significantly lower underpricing. The relationship is economically important, as results show 4.3 percentage points more underpricing in (or close to) the top ten counties according to expert density than in those outside the top 50. In comparison, the relationship between underpricing and proximity of issuers to large population centers is weaker (albeit significant). Therefore, the number and density of experts - our extended proxy for strong local bias - is a more significant factor for underpricing than the mere number of people living in an area.

In sum, our empirical findings are in line with the predictions of the local bias literature and not easily explained by alternative theories. Although the geographical data naturally requires a relatively descriptive analysis of the hypothesized mechanism, our results are empirically robust to various data adjustments and to alterations in the definition of proximity. Also, our analysis verifies that the geographical pattern in IPO underpricing concentrates fully on the first day of trading, with no systematic pattern or reversal in returns beyond that day. This is consistent with geographical differences in local information and corresponding uncertainty concerning IPO value, which is revealed and fully reflected in market prices as soon as firms become publicly traded. 
In short, this paper reveals a previously undocumented local effects pattern in underpricing, without aiming to challenge or rule out existing theories on underpricing, such as those of ownership and control (Brennan and Franks, 1997; Stoughton and Zechner, 1998), institutional explanations (Tinic, 1988; Ruud, 1993), varying issuer objective functions (Loughran and Ritter, 2004), differentiated underwriting services, and localized competition (cf. Liu and Ritter, 2011), to name a few. ${ }^{1}$ Instead, this paper complements existing work by indicating that informational uncertainty and variation in local bias across geographical regions can help to explain a sizeable portion of the underpricing puzzle.

In the remainder of the paper, section 2 provides a description of the methodology and data, while sections 3 and 4 present key results and robustness checks. Finally, section 5 discusses the overall findings and concludes.

\section{Methodology and Data}

Data on IPO underpricing comes from the Security Data Corporation's (SDC) New Issues database and covers all public U.S. companies issuing equity from January 1986 to December 2014. Table 1 presents summary data on IPO underpricing, e.g., showing that the average level of underpricing is $18.1 \%$ for $1986-2014$. The table further reports the level of underpricing for rural and urban firms. To summarize - while briefly withholding the details on the geographic classification - the table reports an average level of $15.2 \%$ IPO underpricing for rural firms, compared to $25.0 \%$ for urban firms. This geographical pattern in underpricing is persistent over time, as demonstrated by the fact that rural firms are less underpriced for 26 of the 29 years in the 1986-2014 sample period. Before further exploring this geographical pattern in IPO underpricing in the next section, we provide a presentation

\footnotetext{
1 The vastness of the literature precludes any attempt to provide an exhaustive list, though seminal work on asymmetic information by, e.g., Rock (1986), Ibbotson (1975), Baron and Holmström (1980), and Benveniste and Spindt (1989) are worth mentioning.
} 
of the conceptualization of proximity measures, which ultimately allows us to classify firms as either rural or urban.

First, we follow a number of authors, including Coval and Moskowitz (2001), Malloy (2005), Loughran and Schultz (2005), Seasholes and Zhu (2010), and John, Knyazeva, and Knyazeva (2011), and use the zip code of corporate headquarters (obtained for all companies from Compustat) as a proxy of corporate location. Then, to capture the remoteness of companies, we follow Loughran and Schultz's (2005) approach, which uses the physical distance between companies and one of the ten largest population centers in the U.S. (cf. Appendix). More precisely, our starting point for measuring proximity is the distance between a company's zip code and the closest ten most populated counties in the U.S. ${ }^{2}$

However, as Grinblatt and Keloharju (2001) and Bernile, Kumar, and Sulaeman (2012) show, local bias may be related to low investor sophistication rather than merely small population size. Thus, to capture the proximity of companies to sophisticated investors, we measure the distance between company location and the top ten places of financial employment. To create such a measure, we use the County Business Patterns database of the U.S. Census Bureau, which provides annual employment data for all U.S. counties broken down by sector. Specifically, employment in the financial sector is based on the number of employees in the North American Industry Classification System (NAICS) sector 523, which covers securities, commodity contracts, and investments. ${ }^{3}$ We use NAICS sector 523 as it

2 This distance is calculated with the Haversine formula for all firms, which gives the shortest path between two points on the surface of a sphere (i.e., as the crow files between any two points). More precisely, let $r$ be the radius of the earth and $\left(\gamma_{a}, \lambda_{a} ; \gamma_{b}, \lambda_{b}\right)$ be the geographical latitude and longitudes of points $a$ and $b$ (the central point of a firm's zip code), where their difference is noted by $\Delta \gamma, \Delta \lambda$. Then the distance between the two points is calculated as:

$$
\text { Distance }=2 r \arcsin \sqrt{\sin ^{2} \frac{\Delta \gamma}{2}+\cos \gamma_{a} \cos \gamma_{b} \sin ^{2} \frac{\Delta \lambda}{2}}
$$

${ }^{3}$ More specifically, NAICS code 523 covers the following ten specific professions within finance: 1) investment banking and securities dealing, 2) securities brokerage, 3) commodity contracts dealing, 4) commodity contracts brokerage, 5) securities and commodity exchanges, 6) miscellaneous intermediation, 7) portfolio management, 8) investment advice, 9) trust, fiduciary, and custody activities, and 10) other miscellaneous financial investment activities. For data prior to the introduction of NAICS in 1998, we use corresponding employment numbers 
represents the concentration of financial expertise most relevant to stock market investments (Wójcik, 2011). Finally, in addition to considering the absolute number of financial sector employees, we also measure the distance between companies and the top ten places of financial employment expressed as a share of total population. These two novel measures allow us to capture both the amount and the density of the available financial expertise. Our aim is thus to test the relationship between IPO underpricing and proximity of companies to centers of financial expertise as well as population. As the literature suggests that local bias is likely stronger in areas of low financial expertise, we expect underpricing to be particularly low in those areas, compared to areas with merely a sparse population. Panel A in Table 2 summarizes the average distance in miles of each company to the closest center of high population or financial expertise.

The Appendix contains a ranking of counties according to population, expert employment, and expert density. The rankings differ significantly. For example, while the central counties of Boston and San Francisco feature among the top ten places according to expert employment and density, they are not among the most populous counties. On the other hand, the central counties of Houston and Phoenix feature among the most populous areas but are not among the top centers of financial expertise. This confirms that the different measures are likely to represent different notions of proximity. The complementarity of the three proximity measures is further confirmed by calculating their correlation coefficients. The correlation between the average number of miles-to-population to either the employment or density measures is only partial (0.51 and 0.42 , respectively). This underlines the important distinction to be made between proximity to experts versus merely population. In contrast, and perhaps unsurprisingly, the correlation between the average distance to expert

based on Standard Industrial Classification (SIC) codes, where the linkage between NAICS and SIC codes is obtained from U.S. Census conversation tables. 
employment and expert density is high (0.87). The difference between the two variables in conceptual terms, however, justifies the use of both measures in the analysis.

To control for other factors that may correlate with underpricing, we obtain various data on firm and IPO characteristics. This includes information on firm age and underwriter reputation, collected by Loughran and Ritter (2004), and on, e.g., bookrunners, IPO proceeds, and venture capital backing provided by the SDC database. Company characteristics in the year of issue (size, sector, listing venue, etc.) are obtained from financial statement data, which is available through the CRSP/Compustat Merged Database (CCM). Panel A in Table 2 presents summary statistics on these primary firm and IPO characteristics. Lastly, calendaryear fixed effects are included in the econometric specification to control for market cycles, while industry effects are captured by a comprehensive set of 19 NAICS-classified industry dummies, which consequently works to filter out any expected industry variation in underpricing, for example, if high-tech industries exhibit more underpricing due to the higher information uncertainty intrinsic to those sectors (cf. Kennedy, Sivakumar, and Vetzal, 2006; Chambers and Dimson, 2009). ${ }^{4}$

\section{Key Results}

To compare IPO underpricing across geographical regions, we define standard proximity dummies using a procedure modeled after Loughran and Schultz (2005). The variable Rural $_{\text {Population }}$ takes the value of 1 if the company is headquartered 100 miles or more from one of the top 50 counties in terms of population, and the value of 0 if the company is

\footnotetext{
${ }^{4}$ Ideally, also having detailed ownership data would allow a more direct test of the local bias hypothesis, since, e.g., Jenkinson and Jones (2004) point out that many IPOs are oversubscribed and investments banks allocate shares to their own clients. However, our approach is motivated by not only the literature indicating a stronger local bias in rural areas, but also by the fact that the local bias hypothesis does not rely on rural investors holding major stakes in rural firms in order for a geographical price differential to emerge. As long as rural investors possess superior information on local firms (relative to urban investors' local knowledge of urban firms), this can in itself be sufficient to create a price differential between rural and urban stock, no matter how small the stakes and the corresponding price difference. Whether this geographical price difference arises is the empirical question we explore in the next section.
} 
headquartered less than 100 miles from one of the top ten counties in terms of population. Furthermore, as discussed above, we introduce two additional proximity measures based on the amount and density of available financial expertise, which are more likely to capture local bias and thereby geographical differences in underpricing. Specifically, the variable $\operatorname{Rural}_{\text {Expert.mployment }}\left(\operatorname{Rural}_{\text {Expert density }}\right)$ takes the value of 1 if the company is headquartered 100 miles or more away from one of the top 50 counties in terms of expert employment (expert density), and the value of 0 if the company is headquartered less than 100 miles from one of the top ten counties in terms of expert employment (expert density). Thus, for each of these three dummy variables, companies with a value of 1 are referred to as 'rural', and those with a value of 0 as 'urban', while keeping in mind that the definitions are varied and extend beyond those used in the existing literature. Akin to Loughran and Schultz (2005), we omit the middle category of firms that cannot be distinctively classified as either rural or urban (i.e., those more than 100 miles away from the top ten counties, but within 100 miles of the top 11-50 counties). To illustrate, figure 1 shows the scope of rural areas in the U.S. (shaded gray) defined based on employment in NAICS 523, as well as explicitly listing the ten counties with the largest absolute employment in NAICS 523. Firms in the excluded middle category are located inside the white 100-mile radius circles not associated with one of these top ten counties.

Panel B of Table 2 shows that this procedure results in a working sample of 1,902 rural and urban firms when the classification is based on proximity to population centers, and, similarly, 2,528 (2,545) sample firms when classifying firms based on proximity to experts (expert density). The same panel also reports the number of observations available for each control variable. In the working sample of 1,902 firms defined based on proximity to population, there are 1,517 firms with available age data and 1,825 firms with asset data, etc. Restricting on the joint data availability of control variables naturally decreases the conditional 
sample size, as also illustrated in Table 2. For example, the sample of 1,902 firms (defined in terms of proximity to population) drops to 1,517 firms once restricting on availability of age data, then down to 1,495 observations when additionally restricting on availability of asset data, etc. Conditioning on the data availability of all control variables results in 1,403 observations in the working sample (respectively, 1,897 and 1,918 observations when classifying firms based on proximity to expert employment and expert density). Lastly, as no geographical categorization is perfect, section 4 also considers several alternative proximity measures to the three benchmark measures described above.

\section{Portfolio sorts}

Before applying a more technical regression methodology that includes all controls, it is useful to briefly present the raw data on IPO underpricing across the geographical definitions. Table 3 presents the average level of IPO underpricing for both rural and urban firms, based on the three different definitions of proximity (cf. Table 1, which only reports figures based on expert density). Rural firms exhibit a significantly lower level of underpricing than urban firms for each definition of proximity. As we move from the definition based on population to the two based on expert employment and expert density, the difference in underpricing between urban and rural firms grows (e.g., 9.76 percentage-point difference for expert density, which is consistent with the bottom row in Table 1). This difference conforms to the idea that the number and density of experts better captures differences in local bias, and thereby produces a sharper difference in underpricing than merely the number of people living in an area.

The results are consistent between equally-weighted and age-weighted portfolios. Existing research shows firm age as a principal variable related to IPO underpricing (e.g., Loughran and Ritter, 2004), since investors intuitively face less uncertainty about the IPO value of older 
firms, e.g., due to easier forecasting of cash flows for firms with a more established past. Consistently, the average level of underpricing in Table 3 decreases across all subsamples when weighting older firms more heavily. But, most notably, urban firms remain significantly more underpriced than rural firms, where the gap widens in magnitude and significance as we move from population to expert-based proximity measures. Next, to further account for other possible determinants of IPO underpricing, we turn to a regression-based analysis.

\section{Multivariate analysis}

Table 4 presents the results of regressing IPO underpricing on proximity measures and relevant control variables. In all regressions the coefficient of proximity is negative and significant, implying that rural areas are associated with lower underpricing. Consistent with results in Table 3, as we compare rurality defined based on population to that defined based on expert density, the value and the significance of the proximity coefficient grows, which is consistent with local bias being stronger in areas where financial expertise is most sparse. More specifically, the result for proximity to centers of dense financial expertise is significant at the $1 \%$ level, showing that, on average, rural companies experience 4.34 percentage points less underpricing relative to urban companies when including the full set of control variables (cf. regression (9)). Moreover, this is an economically significant result, taking into account that the average level of underpricing in the sample is 18.1 percentage points (cf. Table 1).

Coefficients on control variables largely conform to existing empirical literature. Firms going public at an older age exhibit less underpricing, which - as noted above - can be explained by investors having more historical information, familiarity, and knowledge about them, and thus face lower information uncertainty (Habib and Ljungqvist, 2001; Chambers and Dimson, 2009). While some studies point to a negative relationship between size and underpricing (e.g., Banjerjee, Dai, and Shrestha, 2011), the results here are more mixed due to 
the common component between age and asset size. Specifically, if firm age is excluded from the regressions, the coefficient on size becomes negative (not reported). The relationship between underpricing and underwriter reputation is mostly positive (although insignificant), in line with Loughran and Ritter (2004), who compile this variable and conjure that underwriters with the best analysts have leverage to underprice more, thus lowering the risk of underwriting. More bookrunners are mostly associated with less underpricing (insignificant), which conforms with our expectations that putting more effort into an IPO, other things being equal, should result in a closer alignment between the offer price and the value of the company. Firms going public on NASDAQ experience more underpricing (as documented by Leone, Rock, and Willenborg, 2007) and firms backed by venture capital also exhibit more underpricing. ${ }^{5}$ Finally, and notably, the explanatory power is consistent in magnitude with existing empirical studies evaluating factors of underpricing (e.g., Chambers and Dimson, 2009; Banjerjee, Dai, and Shrestha, 2011).

\section{Alternative Specifications}

Table 5 presents further regression results investigating the sensitivity of our findings on lower underpricing among rural firms. Since the definition of rural companies based on expert density is the most intuitive and novel methodological contribution of our study, we apply this notion of proximity in our robustness tests (except in regressions (5-8) in Table 5, where new alternative proximity definitions are examined). To fully challenge the results, we also keep the entire list of previously described explanatory variables as controls (cf.

\footnotetext{
5 The literature is mixed with regards to the predicted impact venture capital backing has on IPO underpricing. On one hand, venture capitalists (VC) tend to cluster geographically (e.g., in Silicon Valley, cf. Castilla, 2003) and exhibit local bias to lower information asymmetry and the cost of monitoring (Cumming and Dai, 2010). Other things being equal, this predicts less IPO underpricing in active VC regions. Early research supports this (e.g., Barry et al., 1990; Megginson and Weiss, 1991; Schultz, 1993), whereas more recent studies present opposing empirical evidence, i.e., higher levels of underpricing among VC-backed issues (Hamao et al., 2000; Bradley and Jordan, 2002; Brav and Gompers, 2002; Loughran and McDonald, 2013). Consistent with the current literature, regressions (6) and (9) in Table 4 show that VC-backed IPOs are significantly more underpriced. This, in part, follows from these working samples including urban firms defined as being close to financial centers, such as New York, for which the VC variable correlates relatively more with IPO underpricing.
} 
regressions (3), (6), and (9) in Table 4), although for brevity, their estimates are excluded from the reported results in Table 5.

First, to control for the impact of New York as the largest concentration of IPOs and expert density (cf. Appendix, Panel C), we run the analysis on a sample excluding companies headquartered in New York (regression (1)). The resulting coefficient for rural companies is significant at the $1 \%$ level and even larger than for the sample of companies including New York. In other words, the difference between underpricing in New York and the rest of the country does not drive the results.

Regression (2) explores the possibility that underpricing may be related to the time zone of the IPO issuers. An absolute majority of IPOs takes place on the NYSE or the NASDAQ, which both follow trading hours adapted to Eastern Standard Time. As local investors are particularly active not only in holding shares, but also in buying and selling (Grinblatt and Keloharju, 2001; Loughran and Schultz, 2004), it is possible that trading on the IPO day for companies headquartered on the East Coast is particularly high, as local traders do not need to adjust their working day to the trading hours of the stock exchange. As we move to companies headquartered further west, the misalignment between the working hours of local traders in these times zones and stock exchange trading hours grows, which may depress trading activity on the IPO day. The resulting pattern of trading activity may in turn influence the degree of underpricing.

To address this issue, regression (2) adds eight binary dummies, one for each of the U.S. time zones (excluding one to avoid collinearity, though not reported to conserve space). It should be emphasized that this is a very restrictive specification, since adding time zone dummies is effectively equivalent to adding geographic control variables, which naturally may influence the coefficient estimate of rurality. Nonetheless, despite the inevitable correlation between time zones and rurality, regression (2) shows that the proximity measure remains 
statistically significant at the $10 \%$ level. In other words, the relatively low underpricing of rural firms is not merely the product of regional differences or the concentration of underpriced firms in a particular time zone, whether on the East Coast, West Coast, or anywhere in between.

Next, we explore whether the geographical variation in underpricing is driven by different local effects across firm size categories. For example, it can be argued that local effects should primarily be present among small firms, since i) they possess relatively less information uncertainty and/or ii) the offer price of big firms is relatively more influenced by factors such as institutional investor demand elicited during the book-building period. Although we already control for firm size, we further explore this in regression (3) by restricting the sample to the top quartile of firms in terms of asset value. The results show that restricting the sample to the largest set of firms does not alter the conclusion that rural firms are significantly less underpriced compared to urban firms, in fact the relationship grows in magnitude.

Regression (4) controls for upward revisions in the offer price. This is motivated by the partial adjustment phenomenon termed by Ibbotson, Sindelar, and Ritter (1988). Hanley (1993) documents that if firms positively revise their offer price as favorable information is revealed during the pre-issue period, greater IPO underpricing tends to result. This is due to firms only partially adjusting their offer price to the newly revealed information, implying that firms with upwards revisions in offer price are more likely to experience relatively higher levels of underpricing. ${ }^{6}$ The literature (e.g., Bradley and Jordan, 2002) extensively documents this relationship between price revisions and IPO underpricing. Upward revisions are defined as the percentage upward revision in the offer price from the mid-point of the filing range, if the offer price is greater than the mid-point, otherwise it is zero (see, e.g., Bradley and Jordan, 2002; Loughran and Ritter, 2002; Lowry and Schwert, 2002; Da, Engelberg, and Gao, 2013;

${ }^{6}$ Benveniste and Spindt (1989) further explain why prices only partially adjust to demand, arguing that this is a result of informed investors being compensated for revealing information in the book-building process. 
Loughran and McDonald, 2013). In short, regression (4) reveals that this partial adjustment measure is significantly correlated with IPO underpricing, but the proximity measure remains statistically significant. ${ }^{7}$ In other words, upward revisions in the offer price are significantly positively related to IPO underpricing (as expected), but it does not alleviate nor replace the pattern between proximity and IPO underpricing. ${ }^{8}$

In the remainder of Table 5, the definition of proximity is modified in order to test the robustness of our central proximity specification (physical distance to centers of expert density). First, in regression (5), we use a narrower definition of proximity, with a firm considered rural if it is headquartered 100 miles or more away from one of the top 75 (instead of 50) counties in terms of expert density, and urban if it is headquartered less than 100 miles away from one of the top 5 (instead of 10). With rural firms now being 'more rural' than in our baseline model, and urban firms 'more urban', we would expect the geographical pattern to remain significant, which is confirmed in regression (5). In regression (6), we conversely use a broader definition, where a firm is considered rural if it is headquartered 100 miles or more away from the top 25 counties in terms of expert density, and urban if it is less than 100 miles away from the top 20. This definition makes the difference between rural and urban firms less sharp and should intuitively lead to a lower geographical difference in underpricing.

\footnotetext{
${ }^{7}$ As availability of the mid-point of the filing range is severely restrictive, we choose to retain a workable sample size by dropping the most data-scarce variable, namely firm age, which becomes insignificant when combined with the partial adjustment term. Due to the data restrictions the partial adjustment term imposes, it is not included in other regressions in our analysis.

${ }^{8}$ Within our setting, upward offer price revisions can also be considered to partially reflect changes in investor attention and subsequent demand. More specifically, an alternative hypothesis for the observed pattern in IPO underpricing across geographical locations is that urban IPOs, on average, receive more attention from investors, resulting in higher demand and thereby higher first-day returns for urban IPOs. For example, Barber and Odean (2008) and Da, Engelberg and Gao (2011) argue that investor attention correlates with buying pressure (see also Gervais, Kaniel and Mingelgrin, 2001; Hou, Peng and Xiong, 2009), while Mondria and Wu (2012) further show that abnormal local attention predicts returns. Although direct measures of investor attention - e.g., quantitative data on media coverage of individual IPOs - are generally unavailable, the upward revision in offer price can be argued to partially correlate with investor attention, since firms receiving considerable investor attention may adjust their offering price in response to this. Thus, while our empirical findings do not rule out other theories of IPO underpricing (nor are they meant to), regression (4) supports that the observed geographical pattern is not easily explained by geographical differences in investor attention. However, other measures are arguably more suitable for capturing investor enthusiasm and interest, if the objective is to directly test the hypotheses of investor attention.
} 
This is confirmed in regression (6), where the coefficient on proximity is smaller in magnitude but still highly significant. Regressions (5) and (6) imply that the results are not driven by an arbitrary definition of rural and urban firms.

Finally, in regressions (7) and (8), we define rural companies on the basis of distance to centers with a large total population (7) and expert population (8) per square mile. As U.S. counties differ considerably in terms of their total area, these measures may better capture the urban or rural character of counties compared to the absolute number of residents or experts. Using the number of people per square mile to define rurality leads to a coefficient of proximity $(-3.76)$ similar in magnitude and significance to that for the total population presented in Table 4 (-3.57). Also, the result for the number of experts per square mile $(-3.90)$ is similar compared to the results based on total employment in Table 4 (-3.69). Also of note,

the pattern across proximity definitions remains unchanged, as the coefficient for proximity based on population per square mile (-3.76) is still weaker than the measure based on experts per square mile $(-3.90)$ or expert density in the population (-4.34 in Table 4). This is again consistent with higher local bias in areas where the local population has less expertise in securities business, compared to areas that simply have a small population or a low population density.

\section{Beyond the First Trading Day}

For completeness, we conclude by examining whether the geographical pattern in underpricing extends beyond the first trading day. If it does, it would suggest that urban firms consistently outperform rural firms and thus that the relatively higher first-day returns are simply a reflection of that. If, however, there is no systematic pattern in returns when looking beyond the first trading day, it indicates that rural and urban firms are not systematically different in ability, but rather that there is a geographical difference that pertains specifically 
to the first trading day. This would be consistent with the hypothesis that the difference originates from uncertainty about IPO value, which varies across geographical areas (e.g., due to strong local bias and superior information in rural areas) and is fully revealed in different first-day returns. In other words, any such pre-IPO uncertainty and informational diversity should appear as soon as the company becomes publicly traded and all available information becomes reflected in market prices.

Table 6 repeats the previous analysis for realized stock returns after the first day of trading. We separately examine the cumulative return in i) the first week of trading following the initial trading day (i.e., excluding the first day of trading); ii) the remainder of the first month (weeks 2-4); iii) months 2-3; iv) months 4-6; and, finally, v) months 0-6 following the offering (excluding the first day of trading). As before, we focus our analysis on proximity defined based on expert density (NAICS sector 523 employment/population). For a very small number of firms, market prices are unavailable beyond the first trading day, explaining the slight decrease in observations compared to Tables 2-4.

Panel A of Table 6 reports the cumulative average return for each of the post-IPO periods, showing no systematic difference between returns of rural and urban firms. The difference in returns between rural and urban firms varies from being either positive or negative, and it is only significantly different in three out of ten cases (weeks 2-4 and months 4-6 for equally weighted portfolios, and months 2-3 for age-weighted portfolios). A more extensive regression analysis in Panel B of Table 6 consistently reveals that there is no systematic pattern or statistical significance in any of the corresponding post-IPO periods. Thus, conforming to the underlying hypothesis, the geographical difference in returns is concentrated on the first day of trading. 


\section{Concluding Remarks}

To the best of our knowledge, this is the first paper to relate IPO underpricing to corporate location, thus merging two hitherto separate bodies of literature. We demonstrate that underpricing varies systematically with corporate location, with firms from rural areas exhibiting significantly less underpricing, thus leaving less money on the table than their urban counterparts. Lower IPO underpricing applies particularly to firms from areas distant to centers of financial expertise, rather than just those distant from large centers of population. The lower underpricing of rural firms is consistent with the relative preponderance of local investors, which the literature predicts to invest a large part of their stock portfolio in local firms, and hence have strong incentives to acquire information on these firms.

The famous quote by Mark Twain that Ivkovic and Weisbenner cite in their seminal paper on local bias: "Behold, the fool saith, 'Put not all thine eggs in the one basket ... but the wise man saith, 'Put all your eggs in the one basket and - watch that basket."' (2005, p. 267), lends itself well as an analogy for interpreting the argument presented in our paper. Prior research on the geography of local bias reveals that investors in rural areas with lower levels of education and financial expertise have a stronger tendency to put their eggs in the local basket. Our assertion and evidence suggest that this gives investors in such areas strong incentives to watch the local basket and that companies from such areas are consequently better watched over and obtain IPO prices closer to their post-IPO values. Given how conflicting different theories of IPO underpricing still are, and how elusive the empirical quest for identifying the factors affecting underpricing has proven so far, this is a result of considerable significance.

Our study merges with research on firm location documenting how proximity impacts financial outcomes by facilitating the collection of soft information (see, e.g., Agarwal and Hauswald, 2010, studying the credit market; Gurun and Butler, 2012, studying local media 
coverage and advertising; and Cai et al., 2014, studying mergers and acquisitions). Our study also implies opportunities for further research. The empirical literature on financial geography could be extended by considering other measures of proximity, such as corporate presence in places that do not host corporate headquarters. Specifically, while proximity between investors and corporate headquarters plays a primary role, investors in places where a company has other major operations - or which constitute a major market for the company are likely to be more familiar with the company than others. Similarly, an extended definition of proximity useful within the underpricing literature might consider investors in places visited as a part of an IPO road show, or the locations of underwriters involved in an IPO. Whatever analytical strategies are pursued, looking beyond simple distinctions between rural and urban may be of value by, e.g., considering the role of social, economic, and cultural characteristics engrained in particular places that are likely to shape both local stock market behavior and pricing. 


\section{References}

Agarwal, S. and R. Hauswald. 2010. "Distance and Private Information in Lending." Review of Financial Studies, 23 (7), 2757-2788.

Banjerjee, S., L. Dai, and K. Shrestha. 2011. "Cross-Country IPOs: What Explains Differences in Underpricing?” Journal of Corporate Finance, 17, 1289-1305.

Barber, B.M. and T. Odean. 2008. "All That Glitters: The Effect of Attention and News on the Buying Behavior of Individual and Institutional Investors." Review of Financial Studies, 21 (2), 785-818.

Baron, D.P. and B. Holmström. 1980. "The Investment Banking Contract for New Issues under Asymmetric Information: Delegation and the Incentive Problem." Journal of Finance, 35, 1115-1138.

Barry, C., C. Muscarella, J. Peavy III, and M. Vetsuypens. 1990. "The Role of Venture Capital in the Creation of Public Companies." Journal of Financial Economics, 27, 447-471.

Benveniste, L. M. and P. A. Spindt (1989). "How Investment Bankers Determine the Offer Price and Allocation of New Issues", Journal of Financial Economics, 24, 343-361.

Bernile, G., A. Kumar and J. Sulaeman. 2012. "Home Away from Home: Relevance and Local Investors.” AFA 2012 Chicago Meetings Paper.

Bodnaruk, A. 2009. "Proximity Always Matters: Local Bias When the Set of Local Companies Changes." Review of Finance, 13, 629-656.

Bradley, D.J., and B.D. Jordan. 2002. "Partial Adjustment to Public Information and IPO Underpricing." Journal of Financial and Quantitative Analysis, 37 (4), 595-616.

Brav, A., and P. Gompers. 2003. "The Role of Lock-ups in Initial Public Offerings." Review of Financial Studies, 16, 1-29.

Brennan, M.J. and J. Franks. 1997. "Underpricing, Ownership and Control in Initial Public Offerings of Equity Securities in the UK." Journal of Financial Economics, 45, 391-413.

Cai, Y., X. Tian and H. Xia. 2014. "Locations, Proximity and M\&A Transactions." Working Paper, March.

Castilla, E.J. 2003. "Networks of Venture Capital Firms in Silicon Valley." International Journal of Technology Management, 25 (1/2), 113-135.

Chambers, D. and E. Dimson. 2009. "IPO Underpricing over the Very Long Run.” Journal of Finance, 64, 1407-1443.

Coval, J. and T. Moskowitz. 2001. "The Geography of Investment: Informed Trading and Asset Prices." Journal of Political Economy, 109, 811-841.

Cumming, D. and N. Dai, 2010. "Local Bias in Venture Capital Investments." Journal of Empirical Finance, 17, 362-380.

Da, Z., J. Engelberg and P. Gao. 2011. "In Search of Attention.” Journal of Finance, 66 (5), 1461-1499.

Gervais, S., R. Kaniel and D.H. Mingelgrin. 2001. “The High-Volume Return Premium.” Journal of Finance, 56(3), 877-919. 
Grinblatt, M. and M. Keloharju. 2001. "How Distance, Language, and Culture Influence Stockholdings and Trades." Journal of Finance, 56, 1053-1073.

Gurun, U.G. and A.W. Butler. 2012. "Don't Believe the Hype: Local Media Slant, Local Advertising, and Firm Value.” Journal of Finance, 67(2), 561-597.

Habib, M. and A. Ljungqvist. 2001. "Underpricing and Entrepreneurial Wealth Losses in IPOs: Theory and Evidence." Review of Financial Studies, 14, 433-458.

Hamao, Y., F. Packer, and J. Ritter. 2000. "Institutional Affiliation and the Role of Venture Capital: Evidence from Initial Public Offerings in Japan." Pacific-Basin Finance Journal, 8, 529-558.

Hou, K., L. Peng and W. Xiong. 2009. "A Tale of Two Anomalies: The Implications of Investor Attention for Price and Earnings Momentum.” Working Paper, January 16.

Ibbotson, R. G. (1975). "Price Performance of Common Stock New Issues", Journal of Financial Economics, 2, 235-272.

Ivkovic, Z. and S. Weisbenner. 2005. "Local Does as Local Is: Information Content of the Geography of Individual Investors' Common Stock Investments.” Journal of Finance, 60, 267-306.

Jenkinson, T. and H. Jones. 2004. "Bids and Allocations in European IPO Bookbuilding." Journal of Finance, 59 (5), 2309-2338.

John, K., A. Knyazeva and D. Knyazeva. 2011. "Does Geography Matter? Firm Location and Corporate Payout Policy.” Journal of Financial Economics, 101, 533-551.

Kennedy, D., R. Sivakumar and K. Vetzal. 2006. "The Implications of IPO Underpricing for the Firm and Insiders: Tests of Asymmetric Information Theories." Journal of Empirical Finance, 13, 49-78.

Leone, A., S. Rock and M. Willenborg. 2007. "Disclosure of Intended Use of Proceeds and Underpricing in Initial Public Offerings.” Journal of Accounting Research, 45, 111-153.

Liu, X. and J. Ritter. 2011. "Local Underwriter Oligopolies and IPO Underpricing." Journal of Financial Economics, 102(3), 579-601.

Ljungqvist, A. 2007. "IPO Underpricing." In: Eckbo, B.E. (Ed) Handbook of Corporate Finance: Empirical Corporate Finance (Chapter 7), Elsevier Science, North Holland, 375-422.

Loughran, T. 2007. "Geographic dissemination of information." Journal of Corporate Finance, 13, 675-694.

Loughran, T. and B. McDonald (2013). "IPO First-Day Returns, Offer Price Revisions, Volatility, and Form S-1 Language." Journal of Financial Economics, 109 (2), 307-326.

Loughran, T. and J. Ritter. 2002. "Why Don't Issuers Get Upset about Leaving Money on the Table in IPOs?" Review of Financial Studies, 15, 413-443.

Loughran, T. and J. Ritter. 2004. "Why Has IPO Underpricing Changed over Time?” Financial Management, 33, 5-37.

Loughran, T. and P. Schultz. 2004. "Weather, Stock Returns, and the Impact of Localized Trading Behavior." Journal of Financial and Quantitative Analysis, 39, 343-364.

Loughran, T. and P. Schultz. 2005. "Liquidity: Urban Versus Rural Firms." Journal of Financial Economics, 78, 341-374. 
Lowry, M. and G. W. Schwert. 2002. "IPO Market Cycles: Bubbles or Sequential Learning?" Journal of Finance, 57 (3), 1171-1200.

Malloy, C. 2005. “The Geography of Equity Analysis.” Journal of Finance, 60, 719-755.

Massa, M. and A. Simonov. 2006. "Hedging, Familiarity and Portfolio Choice." The Review of Financial Studies, 19, 633-685.

Megginson, W., and K. Weiss. 1991. "Venture Capitalist Certification in Initial Public Offerings." Journal of Finance, 57, 1171-1200.

Mondria, J. and T. Wu. 2012. "Asymmetric Information and Stock Returns.” Working Paper, August.

Ritter, R. 2014. "Initial Public Offerings: Updated Statistics." bear.warrington.ufl.edu/ritter/IPOs2014Statistics.pdf. Table 8, December 20. Accessed April 21, 2015.

Ritter, R. and I. Welch. 2002. "A Review of IPO Activity, Pricing, and Allocations." Journal of Finance, 57, 1795-1828.

Rock, K. 1986. "Why New Issues Are Underpriced.” Journal of Financial Economics, 15, 187212.

Ruud, J.S. 1993. "Underpricing Price Support and the IPO Underpricing Puzzle." Journal of Financial Economics, 34(2), 135-151.

Schultz, P. 1993. "Unit Initial Public Offerings.” Journal of Financial Economics, 34, 199-299.

Seasholes, M. and N. Zhu. 2010. "Individual Investors and Local Bias." Journal of Finance, 65, 1987-2010.

Stoughton, N.M. and J. Zechner. 1998. "IPO Mechanisms, Monitoring and Ownership Structure." Journal of Financial Economics, 49, 45-78.

Tinic, S.M. 1998. "Anatomy of Initial Public Offerings of Common Stock.” Journal of Finance, 43, 789-822.

Wójcik, D. 2011. The Global Stock Market: Issuers, Investors, and Intermediaries in an Uneven World. Oxford University Press, Oxford. 


\section{Table 1. Overview of IPO underpricing}

This table shows the number of IPOs and average first-day returns (i.e., underpricing) for the 1986-2014 period. Rural firms are defined as those headquartered 100 miles or more away from the top 50 counties in terms of expert density (NAICS sector 523 employment/population), while urban firms are those headquartered less than 100 miles away from the top ten counties. IPOs with an offer price below USD5.00 per share, unit offers, REITs, closed-end-funds, banks, S\&Ls and SPACs are excluded (cf. Ritter and Welch, 2002). All figures are compiled from the Securities Data Company New Issues database.

\begin{tabular}{|c|c|c|c|c|c|c|}
\hline \multirow[b]{2}{*}{ Year } & \multicolumn{2}{|c|}{ All Firms } & \multicolumn{2}{|c|}{ Rural Firms } & \multicolumn{2}{|c|}{ Urban Firms } \\
\hline & $\begin{array}{l}\text { No. of } \\
\text { IPOs }\end{array}$ & $\begin{array}{c}\text { First-day } \\
\text { return }\end{array}$ & $\begin{array}{l}\text { No. of } \\
\text { IPOs }\end{array}$ & $\begin{array}{c}\text { First-day } \\
\text { return }\end{array}$ & $\begin{array}{l}\text { No. of } \\
\text { IPOs }\end{array}$ & $\begin{array}{c}\text { First-day } \\
\text { return }\end{array}$ \\
\hline 1986 & 420 & $9.1 \%$ & 25 & $9.5 \%$ & 57 & $12.2 \%$ \\
\hline 1987 & 299 & $5.6 \%$ & 31 & $6.7 \%$ & 41 & $5.7 \%$ \\
\hline 1988 & 124 & $5.5 \%$ & 7 & $1.5 \%$ & 22 & $5.7 \%$ \\
\hline 1989 & 112 & $10.3 \%$ & 11 & $9.2 \%$ & 18 & $11.9 \%$ \\
\hline 1990 & 133 & $9.4 \%$ & 18 & $10.1 \%$ & 19 & $11.6 \%$ \\
\hline 1991 & 282 & $11.5 \%$ & 28 & $7.5 \%$ & 42 & $12.7 \%$ \\
\hline 1992 & 406 & $10.4 \%$ & 53 & $12.1 \%$ & 84 & $12.3 \%$ \\
\hline 1993 & 550 & $11.8 \%$ & 79 & $13.8 \%$ & 101 & $13.0 \%$ \\
\hline 1994 & 442 & $10.8 \%$ & 61 & $10.4 \%$ & 78 & $12.3 \%$ \\
\hline 1995 & 455 & $22.8 \%$ & 48 & $19.7 \%$ & 94 & $31.2 \%$ \\
\hline 1996 & 669 & $17.1 \%$ & 66 & $15.3 \%$ & 130 & $22.3 \%$ \\
\hline 1997 & 460 & $14.8 \%$ & 63 & $10.6 \%$ & 79 & $17.8 \%$ \\
\hline 1998 & 280 & $21.0 \%$ & 39 & $15.5 \%$ & 44 & $24.6 \%$ \\
\hline 1999 & 439 & $60.4 \%$ & 37 & $59.6 \%$ & 142 & $75.2 \%$ \\
\hline 2000 & 315 & $53.6 \%$ & 35 & $58.8 \%$ & 122 & $61.3 \%$ \\
\hline 2001 & 84 & $13.5 \%$ & 12 & $4.8 \%$ & 21 & $18.9 \%$ \\
\hline 2002 & 80 & $6.8 \%$ & 17 & $2.4 \%$ & 22 & $8.0 \%$ \\
\hline 2003 & 68 & $10.6 \%$ & 7 & $17.3 \%$ & 15 & $14.4 \%$ \\
\hline 2004 & 185 & $10.8 \%$ & 38 & $8.3 \%$ & 62 & $13.3 \%$ \\
\hline 2005 & 164 & $9.8 \%$ & 39 & $9.4 \%$ & 51 & $9.7 \%$ \\
\hline 2006 & 155 & $11.3 \%$ & 33 & $10.5 \%$ & 55 & $14.3 \%$ \\
\hline 2007 & 172 & $11.9 \%$ & 30 & $9.4 \%$ & 64 & $14.7 \%$ \\
\hline 2008 & 20 & $4.2 \%$ & 3 & $-5.7 \%$ & 7 & $-1.0 \%$ \\
\hline 2009 & 35 & $9.6 \%$ & 6 & $1.7 \%$ & 13 & $13.8 \%$ \\
\hline 2010 & 74 & $7.8 \%$ & 14 & $5.3 \%$ & 30 & $9.6 \%$ \\
\hline 2011 & 72 & $13.4 \%$ & 12 & $14.6 \%$ & 31 & $16.2 \%$ \\
\hline 2012 & 90 & $17.4 \%$ & 22 & $8.2 \%$ & 41 & $28.3 \%$ \\
\hline 2013 & 146 & $22.7 \%$ & 32 & $21.9 \%$ & 69 & $22.5 \%$ \\
\hline 2014 & 176 & $17.2 \%$ & 40 & $7.5 \%$ & 85 & $18.8 \%$ \\
\hline 1986-1989 & 955 & $7.7 \%$ & 74 & $7.5 \%$ & 138 & $9.2 \%$ \\
\hline 1990-1994 & 1,813 & $11.0 \%$ & 239 & $11.5 \%$ & 324 & $12.5 \%$ \\
\hline 1995-1999 & 2,303 & $26.5 \%$ & 253 & $21.5 \%$ & 489 & $38.9 \%$ \\
\hline $2000-2004$ & 732 & $29.0 \%$ & 109 & $23.9 \%$ & 242 & $37.6 \%$ \\
\hline $2005-2009$ & 546 & $10.7 \%$ & 111 & $8.9 \%$ & 190 & $12.6 \%$ \\
\hline 2010-2014 & 558 & $16.9 \%$ & 120 & $11.9 \%$ & 256 & $19.9 \%$ \\
\hline 1986-2014 & 6,907 & $18.1 \%$ & 906 & $15.2 \%$ & 1,639 & $25.0 \%$ \\
\hline
\end{tabular}




\section{Table 2. Summary statistics}

Panel A: All firms and working samples

This panel reports the descriptive statistics of the key variables to be used in the subsequent analysis. Miles to top population is the distance from a firm's headquarters to the closest top ten counties in the U.S. in terms of population. Similarly, miles to top expert employment is the distance to the closest top ten county in terms of NAICS sector 523 employment (representing securities, commodity contracts, and investments) and miles to top expert density is the distance to the closest top ten county in terms of expert employment relative to population. The three working samples of rural and urban firms are defined as follows: i) population: rural firm if 100 miles or more away from the top 50 counties in terms of population, urban if less than 100 miles away from the top 10; ii) expert employment: rural if 100 miles or more away from the top 50 counties in terms of NAICS sector 523 employment, urban if less than 100 miles away from the top 10; and iii) expert density: rural if 100 miles or more away from the top 50 counties in terms of expert density (NAICS sector 523 employment/population), urban if less than 100 miles away from the top 10 . Age at IPO is the number of years since the founding date of the firm and total assets is given in millions of inflation-adjusted USD at 2000 prices. Underwriter reputation measures the prestige of the underwriter and takes the values 0-9, where a higher value represents a higher rank. The number of bookrunners is the number of managers assuming the responsibility of the bookrunner's role. Proceeds are the amount raised in the IPO from investors in millions of inflation-adjusted USD at 2000 prices, defined as the number of shares offered times the share price (excluding the overallotment option). The venture capital variable is a binary dummy taking the value of 1 if the IPO is backed by venture capital, otherwise it is zero. To dilute the influence of outliers, financial data is winsorized at the $1^{\text {st }}$ and $99^{\text {th }}$ percentiles. The data is obtained from Loughran and Ritter (L\&R) (2004), with updated data files available at Ritter's website, the CRSP/Compustat Merged Database (CCM), the Securities Data Company (SDC) New Issues database, the 2005 U.S. Census (USC), and the County Business Patterns (CBP) database of the U.S. Census Bureau.

\begin{tabular}{|c|c|c|c|c|c|c|c|c|c|c|c|c|}
\hline & \multirow{2}{*}{\multicolumn{5}{|c|}{ All Firms }} & \multicolumn{2}{|c|}{ Population } & \multicolumn{2}{|c|}{ Expert Employment } & \multicolumn{2}{|c|}{ Expert Density } & \multirow[b]{3}{*}{ Data source: } \\
\hline & & & & & & \multirow{2}{*}{$\begin{array}{l}\text { Rural } \\
\text { Mean }\end{array}$} & \multirow{2}{*}{$\begin{array}{l}\text { Urban } \\
\text { Mean }\end{array}$} & \multirow{2}{*}{$\begin{array}{l}\text { Rural } \\
\text { Mean }\end{array}$} & \multirow{2}{*}{$\begin{array}{l}\text { Urban } \\
\text { Mean }\end{array}$} & \multirow{2}{*}{$\begin{array}{l}\text { Rural } \\
\text { Mean }\end{array}$} & \multirow{2}{*}{$\begin{array}{l}\text { Urban } \\
\text { Mean } \\
\end{array}$} & \\
\hline & Mean & Std.dev. & Median & Min & Max & & & & & & & \\
\hline \multicolumn{13}{|l|}{ Geographical characteristics of firms } \\
\hline Miles to top population & 289 & 294 & 228 & 0 & 2,944 & 513 & 24 & - & - & - & - & CCM, USC \\
\hline Miles to top expert employment & 292 & 378 & 52 & 0 & 2,756 & - & - & 579 & 25 & - & - & CCM, CBP \\
\hline Miles to top expert density & 294 & 307 & 195 & 0 & 2,756 & - & - & - & - & 571 & 23 & CCM, USC, CBP \\
\hline \multicolumn{13}{|l|}{ Firm and IPO characteristics } \\
\hline Age at IPO & 17.8 & 23.3 & 9 & 1 & 165 & 12.8 & 21.5 & 23.4 & 15.2 & 20.8 & 15.5 & L\&R (2004) \\
\hline Total assets (mill. USD) & 783 & 5,049 & 99 & 3.6 & 163,379 & 606 & 1,304 & 694 & 787 & 757 & 826 & $\mathrm{CCM}$ \\
\hline \multicolumn{13}{|l|}{ IPO characteristics } \\
\hline Underwriter reputation & 7.2 & 2.2 & 8 & 1 & 9 & 7.2 & 7.4 & 7.2 & 7.7 & 7.4 & 7.7 & L\&R (2004) \\
\hline No. of bookrunners & 1.3 & 0.9 & 1 & 1 & 13 & 1.3 & 1.6 & 1.3 & 1.4 & 1.4 & 1.4 & SDC \\
\hline Proceeds (mill. USD) & 93 & 218 & 43 & 1 & 12,005 & 91 & 137 & 92 & 106 & 108 & 107 & SDC \\
\hline Venture capital backing & 0.38 & 0.49 & 0 & 0 & 1 & 0.25 & 0.32 & 0.27 & 0.55 & 0.33 & 0.54 & SDC \\
\hline
\end{tabular}


This panel reports the number of observations (obs.) available for each variable and the corresponding sample size once conditioning on data availability for that variable. First, merely conditioning on having information on first-day returns gives a total of 1,902 rural and urban firms classified based on proximity to population centers, while using the expert employment (expert density) definition of proximity gives 2,528 (2,545) rural and urban firms (see Appendix for further details on the three different categorizations). The number of observations available for each control variable is reported, for instance, in the working sample of 1,902 firms defined based on proximity to population, where there are, e.g., 1,517 firms with available age data and 1,825 firms with asset data. The conditional sample size decreases as we condition on the data availability of additional control variables. For example, starting from a working sample of 1,902 firms defined in terms of proximity to population, the sample drops to 1,517 firms once restricting on availability of age data then down to 1,495 observations when also restricting on availability of asset data, etc. Restricting on data availability for all control variables results in 1,403 observations (cf. sample size in regression (3) in Table 4).

\begin{tabular}{|c|c|c|c|c|c|c|}
\hline & \multicolumn{2}{|c|}{ Population } & \multicolumn{2}{|c|}{ Expert Employment } & \multicolumn{2}{|c|}{ Expert Density } \\
\hline & No. of obs. & Cond. sample size & No. of obs. & Cond. sample size & No. of obs. & Cond. sample size \\
\hline Non-restricted rural and urban sample & 1,902 & & 2,528 & & 2,545 & \\
\hline \multicolumn{7}{|l|}{ Firm and IPO characteristics } \\
\hline Age at IPO & 1,517 & 1,517 & 2,054 & 2,054 & 2,065 & 2,065 \\
\hline Total assets & 1,825 & 1,495 & 2,412 & 2,023 & 2,446 & 2,038 \\
\hline \multicolumn{7}{|l|}{ IPO characteristics } \\
\hline Underwriter reputation & 1,845 & 1,452 & 2,445 & 1,956 & 2,465 & 1,973 \\
\hline No. of bookrunners & 1,902 & 1,452 & 2,528 & 1,956 & 2,545 & 1,973 \\
\hline Proceeds & 1,902 & 1,452 & 2,528 & 1,956 & 2,545 & 1,973 \\
\hline Venture capital backing & 1,841 & 1,403 & 2,457 & 1,897 & 2,479 & 1,918 \\
\hline
\end{tabular}




\section{Figure 1. Rural areas}

This figure illustrates the definition of proximity in terms of employment in the financial sector (NAICS sector 523, which covers securities, commodity contracts, and investments). The gray shading represents rural areas, which are defined as areas 100 miles or more away from one of the top 50 counties ranked in terms of employment in NAICS sector 523 (see Appendix for exact ranking). Also shown are the top ten cities in counties with the largest number of employees in NAICS sector 523. Firms not classified as either rural or urban are located inside the white 100-mile radius circles not associated with any of the top ten counties. Alaska and Hawaii are classified as rural areas.

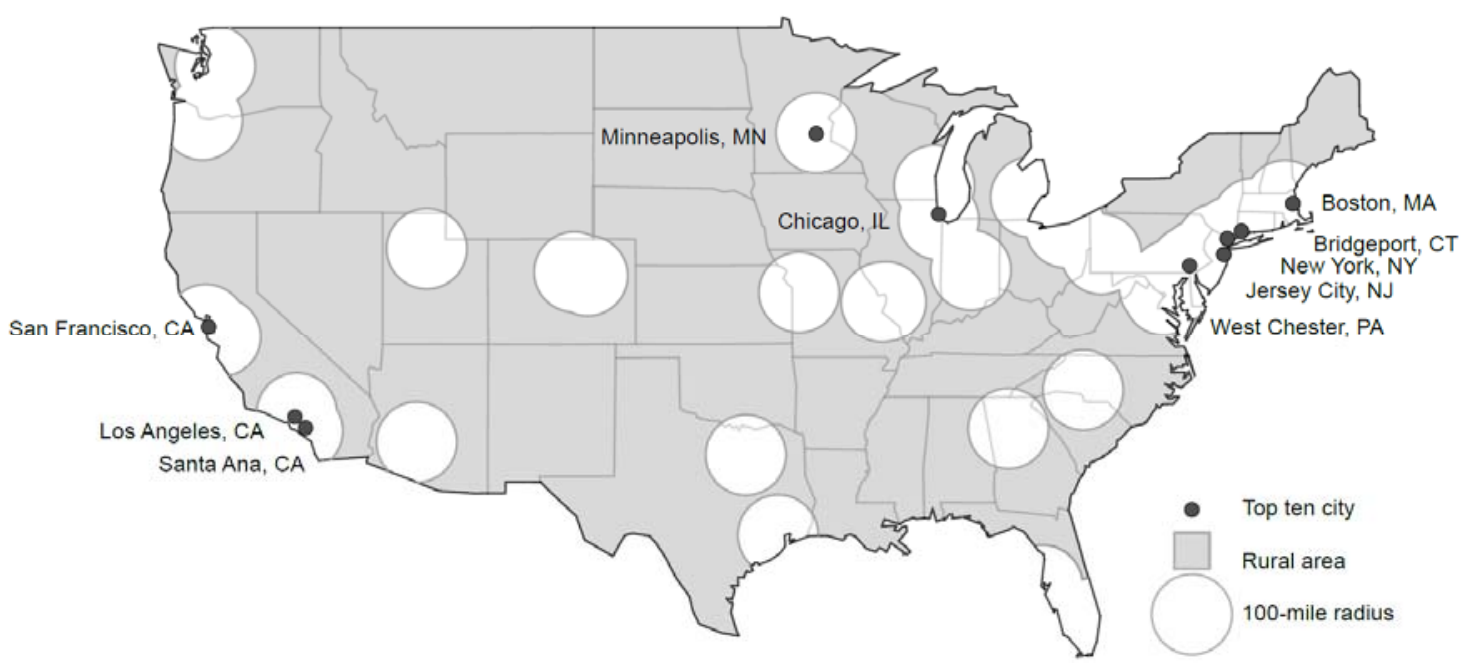




\section{Table 3. Average underpricing across proximity definitions}

This table reports the average level of IPO underpricing (first-day returns) across different definitions of proximity. The proximity measures are defined as follows: i) population: rural firm if 100 miles or more away from the top 50 counties in terms of population, urban if less than 100 miles away from the top 10; ii) expert employment: rural if 100 miles or more away from the top 50 counties in terms of NAICS sector 523 employment, urban if less than 100 miles away from the top 10; and iii) expert density: rural if 100 miles or more away from the top 50 counties in terms of expert density (NAICS sector 523 employment/population), urban if less than 100 miles away from the top 10. The average underpricing is obtained from equally weighted firm portfolios and from age-weighted firm portfolios, where, in the latter case, the average is weighted with the number of years between the founding date of the firm and the IPO date (cf. Loughran and Ritter, 2004). The number of observations (obs.) corresponds to the number of IPOs in each sample, which naturally varies with proximity definitions (cf. Panel B of Table 2). T-statistics (t-stat.) are reported for two-sided tests on whether estimates are different from zero. Statistical significance is indicated at the $10 \%\left(^{*}\right), 5 \%\left(^{* *}\right)$, and $1 \%(* * *)$ level.

\begin{tabular}{|c|c|c|c|c|c|c|}
\hline & \multicolumn{3}{|c|}{ Equally-weighted } & \multicolumn{3}{|c|}{ Age-weighted } \\
\hline & Underpricing & T-stat. & Obs. & Underpricing & T-stat. & Obs. \\
\hline \multicolumn{7}{|l|}{ Population } \\
\hline Rural & $12.66 \%$ & $13.17 * * *$ & 612 & $9.77 \%$ & $10.69 * * *$ & 508 \\
\hline Urban & $16.91 \%$ & $18.07 * * *$ & 1,290 & $14.06 \%$ & $13.90 * * *$ & 1,009 \\
\hline Difference & $-4.26 \%$ & $-3.17 * * *$ & & $-4.29 \%$ & $-3.15^{* * *}$ & \\
\hline \multicolumn{7}{|c|}{ Expert employment } \\
\hline Rural & $14.05 \%$ & $12.06^{* * *}$ & 537 & $10.12 \%$ & $9.69 * * *$ & 449 \\
\hline Urban & $23.89 \%$ & $25.11 * * *$ & 1,991 & $17.07 \%$ & $17.58^{* * *}$ & 1,605 \\
\hline Difference & $-9.85 \%$ & $-6.55^{* * *}$ & & $-6.96 \%$ & $-4.88^{* * *}$ & \\
\hline \multicolumn{7}{|l|}{ Expert density } \\
\hline Rural & $15.21 \%$ & $15.60 * * *$ & 906 & $11.08 \%$ & $13.31 * * *$ & 739 \\
\hline Urban & $24.97 \%$ & $22.84^{* * *}$ & 1,639 & $17.25 \%$ & $16.01^{* * *}$ & 1,326 \\
\hline Difference & $-9.76 \%$ & $-6.66 * * *$ & & $-6.17 \%$ & $-4.54 * * *$ & \\
\hline
\end{tabular}




\section{Table 4. Proximity and underpricing}

This table reports the relationship between IPO underpricing (first-day returns) and different dummy measures of proximity, all of which classify firms as either rural (1) or urban (0). The dummy measures are defined for each firm as follows: i) population: 1 if 100 miles or more away from the top 50 counties in terms of population, 0 if less than 100 miles away from the top 10; ii) expert employment: 1 if 100 miles or more away from the top 50 counties in terms of NAICS sector 523 employment, 0 if less than 100 miles away from the top 10; and iii) expert density: 1 if 100 miles or more away from the top 50 counties in terms of expert density (NAICS sector 523 employment/population), 0 if less than 100 miles away from the top 10. The NASDAQ variable is a binary dummy taking the value of 1 if the IPO occurs at the NASDAQ exchange, 0 otherwise (Leone, Rock and Willenborg (2007) document relatively higher average underpricing on NASDAQ IPOs). All other variables are defined as in Table 2 (summary statistics). The number of observations corresponds to the number of rural and urban IPOs in each regression, which naturally varies with proximity definitions (cf. Panel B of Table 2). T-statistics are reported in parenthesis (calculated based on Huber/White robust standard errors) and significance is indicated at the $10 \%(*), 5 \%(* *)$, and $1 \%(* * *)$ level.

\begin{tabular}{|c|c|c|c|c|c|c|c|c|c|}
\hline & \multicolumn{3}{|c|}{ Population } & \multicolumn{3}{|c|}{ Expert Employment } & \multicolumn{3}{|c|}{ Expert Density } \\
\hline & $(1)$ & (2) & (3) & (4) & $(5)$ & $(6)$ & $(7)$ & $(8)$ & $(9)$ \\
\hline Rural & $\begin{array}{c}-3.48^{* *} \\
(-2.48)\end{array}$ & $\begin{array}{c}-3.41 * * \\
(-2.36)\end{array}$ & $\begin{array}{c}-3.57 * * \\
(-2.37)\end{array}$ & $\begin{array}{c}-5.05^{* * *} \\
(-3.14)\end{array}$ & $\begin{array}{c}-4.58 * * * \\
(-2.80)\end{array}$ & $\begin{array}{c}-3.69 * * \\
(-2.17)\end{array}$ & $\begin{array}{c}-4.85^{* * *} \\
(-3.23)\end{array}$ & $\begin{array}{c}-4.71 * * * \\
(-3.09)\end{array}$ & $\begin{array}{c}-4.34 * * * \\
(-2.75)\end{array}$ \\
\hline Ln(Age at IPO) & $\begin{array}{c}-1.58^{* *} \\
(-2.17)\end{array}$ & $\begin{array}{c}-1.62 * * \\
(-2.15)\end{array}$ & $\begin{array}{l}-1.21 \\
(-1.59)\end{array}$ & $\begin{array}{c}-4.95^{* * *} \\
(-5.40)\end{array}$ & $\begin{array}{c}-4.79 * * * \\
(-5.21)\end{array}$ & $\begin{array}{c}-3.99 * * * \\
(-4.25)\end{array}$ & $\begin{array}{c}-5.07 * * * \\
(-5.92)\end{array}$ & $\begin{array}{c}-4.94 * * * \\
(-5.71)\end{array}$ & $\begin{array}{c}-4.39 * * * \\
(-5.01)\end{array}$ \\
\hline $\operatorname{Ln}$ (Assets) & $\begin{array}{l}-0.17 \\
(-0.32)\end{array}$ & $\begin{array}{c}-2.22 * * \\
(-2.32)\end{array}$ & $\begin{array}{l}-2.11 * * \\
(-2.11)\end{array}$ & $\begin{array}{c}2.45^{* * *} \\
(3.79)\end{array}$ & $\begin{array}{l}-0.68 \\
(-0.55)\end{array}$ & $\begin{array}{c}0.10 \\
(0.08)\end{array}$ & $\begin{array}{c}2.55^{* * *} \\
(4.18)\end{array}$ & $\begin{array}{c}-0.60 \\
(-0.48)\end{array}$ & $\begin{array}{c}0.20 \\
(0.15)\end{array}$ \\
\hline Underwriter reputation & & $\begin{array}{c}0.71 \\
(1.32)\end{array}$ & $\begin{array}{c}0.35 \\
(0.59)\end{array}$ & & $\begin{array}{c}0.54 \\
(0.91)\end{array}$ & $\begin{array}{l}-0.32 \\
(-0.50)\end{array}$ & & $\begin{array}{c}0.66 \\
(1.15)\end{array}$ & $\begin{array}{c}-0.09 \\
(-0.14)\end{array}$ \\
\hline No. of bookrunners & & $\begin{array}{c}0.88 \\
(1.04)\end{array}$ & $\begin{array}{c}1.12 \\
(1.33)\end{array}$ & & $\begin{array}{c}-0.75 \\
(-0.79)\end{array}$ & $\begin{array}{l}-0.55 \\
(-0.58)\end{array}$ & & $\begin{array}{l}-0.46 \\
(-0.48)\end{array}$ & $\begin{array}{c}-0.13 \\
(-0.13)\end{array}$ \\
\hline $\operatorname{Ln}$ (Proceeds) & & $\begin{array}{l}2.30^{*} \\
(1.73)\end{array}$ & $\begin{array}{c}2.78^{* *} \\
(1.98)\end{array}$ & & $\begin{array}{l}4.72^{* *} \\
(2.42)\end{array}$ & $\begin{array}{l}4.95^{* *} \\
(2.52)\end{array}$ & & $\begin{array}{l}4.42^{* *} \\
(2.32)\end{array}$ & $\begin{array}{l}4.59 * * \\
(2.37)\end{array}$ \\
\hline NASDAQ & & & $\begin{array}{l}3.01 * \\
(1.66)\end{array}$ & & & $\begin{array}{c}2.79 \\
(1.34)\end{array}$ & & & $\begin{array}{c}3.21 \\
(1.56)\end{array}$ \\
\hline Venture capital & & & $\begin{array}{c}1.16 \\
(0.56)\end{array}$ & & & $\begin{array}{c}5.63^{* * *} \\
(2.81)\end{array}$ & & & $\begin{array}{c}4.66^{* *} \\
(2.30)\end{array}$ \\
\hline Constant & $\begin{array}{l}-5.91 \\
(-1.17)\end{array}$ & $\begin{array}{l}-9.56 \\
(-1.51)\end{array}$ & $\begin{array}{l}-9.49 \\
(-1.48)\end{array}$ & $\begin{array}{l}-15.30 \\
(-1.30)\end{array}$ & $\begin{array}{l}-12.76 \\
(-1.62)\end{array}$ & $\begin{array}{c}-14.11 * \\
(-1.84)\end{array}$ & $\begin{array}{l}-4.56 \\
(-0.65)\end{array}$ & $\begin{array}{c}-29.20 * * * \\
(-2.67)\end{array}$ & $\begin{array}{c}-16.77^{* *} \\
(-2.19)\end{array}$ \\
\hline Industry fixed effects & Yes & Yes & Yes & Yes & Yes & Yes & Yes & Yes & Yes \\
\hline Year fixed effects & Yes & Yes & Yes & Yes & Yes & Yes & Yes & Yes & Yes \\
\hline Observations & 1,495 & 1,452 & 1,403 & 2,023 & 1,956 & 1,897 & 2,038 & 1,973 & 1,918 \\
\hline - Rural & 501 & 489 & 470 & 443 & 429 & 414 & 731 & 712 & 694 \\
\hline - Urban & 994 & 963 & 933 & 1,580 & 1,527 & 1,483 & 1,307 & 1,261 & 1,224 \\
\hline R-squared & 0.16 & 0.17 & 0.17 & 0.23 & 0.23 & 0.24 & 0.26 & 0.26 & 0.26 \\
\hline
\end{tabular}

28 


\section{Table 5. Robustness and further results}

This table shows further tests and extensions of previously established results in Table 4. All regressions include a constant and the same set of controls as regression (3), (6), and (9) in Table 4, but to conserve space the associated coefficients are not reported in the table. In regressions (1-4) the rural dummy is 1 if the firm is headquartered 100 miles or more away from the top 50 counties in terms of expert density (NAICS sector 523 employment/population) and 0 if it is less than 100 miles away from the top 10 . Regression (1) leaves out firms headquartered in New York. Regression (2) includes eight dummy variables (not reported) for each of the U.S. time zones (based on county-level time zone data from the National Oceanic and Atmospheric Administration's National Weather Service, nsw.noaa.gov). Regression (3) restricts the sample to the top quartile of firms in terms of asset value. Regression (4) defines the variable upward revision as the percentage of upward revision in the offer price from the mid-point of the filing range, if the offer price is greater than the mid-point (otherwise the value is zero). Due to data restrictions, regression (4) includes all firm controls except firm age (insignificant when including the partial adjustment term). In regressions (5-8) the proximity dummy is redefined in various ways. Regression (5) (6) considers a narrower (broader) definition of proximity compared to Table 4, i.e., a firm is considered rural if it is 100 miles or more away from the top 75 (25) counties in terms of expert density, and urban if less than 100 miles away from the top 5 (20). Regression (7) (8) redefines the population (employment) proximity measure reported in Table 4 by adjusting for county square miles, i.e., a firm is considered rural if it is 100 miles or more away from the top 50 counties ranked in terms of population (employment) per square mile, and urban if less than 100 miles away from the top 10 (based on county-level data on square miles of land area from the U.S. Census Bureau). The number of observations corresponds to the number of IPOs in each regression, which naturally varies with data restrictions. T-statistics are reported in parenthesis (calculated based on Huber/White robust standard errors) and significance is indicated at the $10 \%(*), 5 \%(* *)$, and $1 \%$ $(* * *)$ level.

\begin{tabular}{|c|c|c|c|c|c|c|c|c|}
\hline & \multicolumn{4}{|c|}{ General Robustness } & \multicolumn{4}{|c|}{ Definition of Proximity } \\
\hline & $\begin{array}{c}\text { Excl. NY } \\
\text { (1) }\end{array}$ & $\begin{array}{c}\text { Time zone } \\
(2)\end{array}$ & $\begin{array}{c}\text { Big firms } \\
\text { (3) }\end{array}$ & $\begin{array}{c}\text { Partial adj. } \\
\text { (4) }\end{array}$ & $\begin{array}{c}\text { Narrow defn. } \\
\text { (5) }\end{array}$ & $\begin{array}{c}\text { Broad defn. } \\
(6)\end{array}$ & $\begin{array}{c}\text { Pop./sq.mi. } \\
(7)\end{array}$ & $\begin{array}{c}\text { Experts/sq.mi. } \\
(8)\end{array}$ \\
\hline Rural & $\begin{array}{c}-4.83^{* * *} \\
(-2.97)\end{array}$ & $\begin{array}{l}-3.25^{*} \\
(-1.94)\end{array}$ & $\begin{array}{c}-8.66 * * * \\
(-2.72)\end{array}$ & $\begin{array}{c}-4.06 * * \\
(-2.31)\end{array}$ & $\begin{array}{c}-4.09 * * \\
(-2.20)\end{array}$ & $\begin{array}{c}-3.62^{* * * *} \\
(-2.62)\end{array}$ & $\begin{array}{c}-3.76 * * \\
(-2.14)\end{array}$ & $\begin{array}{l}-3.90 * * \\
(-2.54)\end{array}$ \\
\hline Upward revision & & & & $\begin{array}{c}0.85^{* * *} \\
(6.87)\end{array}$ & & & & \\
\hline Control variables & Yes & Yes & Yes & Yes & Yes & Yes & Yes & Yes \\
\hline Industry fixed effects & Yes & Yes & Yes & Yes & Yes & Yes & Yes & Yes \\
\hline Year fixed effects & Yes & Yes & Yes & Yes & Yes & Yes & Yes & Yes \\
\hline Observations & 1,818 & 1,918 & 395 & 966 & 1,609 & 2,622 & 1,881 & 2,130 \\
\hline - Rural & 694 & 694 & 184 & 348 & 498 & 1,145 & 668 & 753 \\
\hline - Urban & 1,124 & 1,224 & 211 & 618 & 1,111 & 1,477 & 1,213 & 1,377 \\
\hline R-squared & 0.26 & 0.28 & 0.39 & 0.31 & 0.27 & 0.23 & 0.25 & 0.24 \\
\hline
\end{tabular}




\section{Table 6. Returns beyond the first trading day}

This table reports the relationship between firm location and stock returns realized after the first day of trading. Specifically, the table separately reports cumulative (cum.) buy-and-hold returns over: i) the first calendar week succeeding the first day of trading (excluding the first day of trading); ii) weeks 2-4 after the first trading day; iii) months 2-3 after the first trading day; iv) months 4-6 after the first day of trading; and v) months 0-6 after the first day of trading (excluding the first day). The underlying proximity definition is based on expert density, where rural firms are those 100 miles or more away from the top 50 counties in terms of expert density (NAICS sector 523 employment/population), and urban firms are less than 100 miles away from the top 10. Panel A reports the cumulative average return for equally weighted firm portfolios and for age-weighted firm portfolios, where, in the latter case, the average is weighted with the number of years between the founding date of the firm and the IPO date (cf. Loughran and Ritter, 2004). Panel B reports a multivariate regression analysis, where the dependent variables are the cumulative returns across different time periods. All explanatory variables are as defined in Tables 2 and 4. The number of observations corresponds to the number of IPOs in the sample, which is slightly lower compared to Tables 2-4 as market prices beyond the first trading day are unavailable for a very small number of firms. T-statistics (T-stat.) are reported in parenthesis (calculated based on robust standard errors clustered by month) and significance is indicated at the $10 \%(*), 5 \%\left(^{* *}\right)$, and $1 \%\left(^{* * *}\right)$ level. Obs.: Observations.

Panel A: Average cumulative returns

\begin{tabular}{|c|c|c|c|c|c|c|}
\hline & \multicolumn{3}{|c|}{ Equally-weighted } & \multicolumn{3}{|c|}{ Age-weighted } \\
\hline & Cum. return & T-stat. & Obs. & Cum. return & T-stat. & Obs. \\
\hline \multicolumn{7}{|l|}{ Week 1} \\
\hline Rural & $-0.16 \%$ & -0.63 & 905 & $0.11 \%$ & 0.32 & 738 \\
\hline Urban & $-0.22 \%$ & -1.00 & 1,635 & $0.10 \%$ & 0.35 & 1,323 \\
\hline Difference & $0.07 \%$ & 0.20 & & $0.01 \%$ & 0.04 & \\
\hline \multicolumn{7}{|l|}{ Weeks 2-4 } \\
\hline Rural & $2.38 \%$ & $4.68^{* * *}$ & 897 & $1.91 \%$ & $2.98^{* * *}$ & 731 \\
\hline Urban & $4.65 \%$ & $9.81 * * *$ & 1,620 & $3.00 \%$ & $5.72 * * *$ & 1,313 \\
\hline Difference & $-2.27 \%$ & $-3.26 * * *$ & & $-1.09 \%$ & -1.32 & \\
\hline \multicolumn{7}{|l|}{ Months 2-3 } \\
\hline Rural & $2.40 \%$ & $2.77 * * *$ & 894 & $-0.19 \%$ & -0.19 & 728 \\
\hline Urban & $2.61 \%$ & $3.53^{* * *}$ & 1,617 & $3.25 \%$ & $3.50^{* * *}$ & 1,309 \\
\hline Difference & $-0.21 \%$ & -0.19 & & $-3.44 \%$ & $-2.53 * *$ & \\
\hline \multicolumn{7}{|l|}{ Months 4-6 } \\
\hline Rural & $0.97 \%$ & 0.99 & 893 & $0.55 \%$ & 0.40 & 728 \\
\hline Urban & $-1.15 \%$ & -1.40 & 1,615 & $-0.48 \%$ & -0.48 & 1,307 \\
\hline Difference & $2.12 \%$ & $1.66^{*}$ & & $1.03 \%$ & 0.60 & \\
\hline \multicolumn{7}{|l|}{ Months 0-6 } \\
\hline Rural & $6.18 \%$ & $4.01 * * *$ & 891 & $2.55 \%$ & 1.39 & 727 \\
\hline Urban & $5.52 \%$ & $4.25^{* * *}$ & 1,606 & $5.42 \%$ & $3.39 * * *$ & 1,302 \\
\hline Difference & 0.66 & 0.33 & & $-2.87 \%$ & -1.18 & \\
\hline
\end{tabular}


Panel B: Multivariate regression analysis

\begin{tabular}{|c|c|c|c|c|c|}
\hline & $\begin{array}{c}\text { Week } 1 \\
(1) \\
\end{array}$ & $\begin{array}{c}\text { Weeks 2-4 } \\
(2) \\
\end{array}$ & $\begin{array}{c}\text { Months 2-3 } \\
\text { (3) } \\
\end{array}$ & $\begin{array}{c}\text { Months 4-6 } \\
\text { (4) }\end{array}$ & $\begin{array}{c}\text { Months 0-6 } \\
\text { (5) } \\
\end{array}$ \\
\hline Rural & $\begin{array}{l}-0.05 \\
(-0.11)\end{array}$ & $\begin{array}{l}-0.90 \\
(-1.10)\end{array}$ & $\begin{array}{l}-1.41 \\
(-0.98)\end{array}$ & $\begin{array}{c}1.15 \\
(0.74)\end{array}$ & $\begin{array}{l}-0.23 \\
(-0.10)\end{array}$ \\
\hline Ln(Age at IPO) & $\begin{array}{c}0.23 \\
(1.04)\end{array}$ & $\begin{array}{c}-0.04 \\
(-0.10)\end{array}$ & $\begin{array}{c}-0.93 \\
(-1.31)\end{array}$ & $\begin{array}{l}-1.00 \\
(-1.31)\end{array}$ & $\begin{array}{l}-2.05^{*} \\
(-1.72)\end{array}$ \\
\hline $\operatorname{Ln}$ (Assets) & $\begin{array}{c}0.80^{* *} \\
(2.36)\end{array}$ & $\begin{array}{c}1.98^{* * *} \\
(3.14)\end{array}$ & $\begin{array}{c}3.63 * * * \\
(4.27)\end{array}$ & $\begin{array}{c}2.82^{* * *} \\
(2.63)\end{array}$ & $\begin{array}{c}9.17 * * * \\
(5.26)\end{array}$ \\
\hline Underwriter reputation & $\begin{array}{c}0.04 \\
(0.24)\end{array}$ & $\begin{array}{c}0.99 \text { *** } \\
(3.37)\end{array}$ & $\begin{array}{l}0.91 * \\
(1.70)\end{array}$ & $\begin{array}{c}0.16 \\
(0.27)\end{array}$ & $\begin{array}{c}2.15^{* *} \\
(2.55)\end{array}$ \\
\hline No. of bookrunners & $\begin{array}{l}-0.12 \\
(-0.37)\end{array}$ & $\begin{array}{c}1.05^{* *} \\
(2.53)\end{array}$ & $\begin{array}{c}0.21 \\
(0.29)\end{array}$ & $\begin{array}{l}-0.92 \\
(-1.09)\end{array}$ & $\begin{array}{c}-0.36 \\
(-0.28)\end{array}$ \\
\hline Ln(Proceeds) & $\begin{array}{l}-0.68 \\
(-1.32)\end{array}$ & $\begin{array}{c}-3.27 * * * \\
(-3.27)\end{array}$ & $\begin{array}{c}-5.92 * * * \\
(-4.79)\end{array}$ & $\begin{array}{l}-3.01 * \\
(-1.96)\end{array}$ & $\begin{array}{c}-12.48^{* * *} \\
(-5.54)\end{array}$ \\
\hline NASDAQ & $\begin{array}{l}1.05^{* *} \\
(2.15)\end{array}$ & $\begin{array}{c}2.47 * * \\
(2.45)\end{array}$ & $\begin{array}{c}3.37 * * \\
(2.15)\end{array}$ & $\begin{array}{l}3.32^{*} \\
(1.92)\end{array}$ & $\begin{array}{c}10.53^{* * *} * \\
(4.17)\end{array}$ \\
\hline Venture capital & $\begin{array}{l}-0.06 \\
(-0.12)\end{array}$ & $\begin{array}{c}3.55^{* * *} \\
(3.60)\end{array}$ & $\begin{array}{l}-0.68 \\
(-0.41)\end{array}$ & $\begin{array}{l}-1.96 \\
(-1.05)\end{array}$ & $\begin{array}{c}-0.01 \\
(-0.00)\end{array}$ \\
\hline Constant & $\begin{array}{c}3.51 \\
(0.65)\end{array}$ & $\begin{array}{c}-10.44 * * \\
(-2.04)\end{array}$ & $\begin{array}{l}-0.78 \\
(-0.05)\end{array}$ & $\begin{array}{l}-6.60 \\
(-0.66)\end{array}$ & $\begin{array}{l}-1.98 \\
(-0.12)\end{array}$ \\
\hline Industry fixed effects & Yes & Yes & Yes & Yes & Yes \\
\hline Year fixed effects & Yes & Yes & Yes & Yes & Yes \\
\hline Observations & 1,915 & 1,911 & 1,904 & 1,902 & 1,895 \\
\hline - Rural & 693 & 690 & 687 & 687 & 686 \\
\hline - Urban & 1,222 & 1,221 & 1,217 & 1,215 & 1,209 \\
\hline R-squared & 0.03 & 0.13 & 0.07 & 0.09 & 0.14 \\
\hline
\end{tabular}




\section{Appendix. Ranking and Summary of Counties}

The three panels in the Appendix rank U.S. counties according to their: a) estimated population in the 2005 U.S. Census; b) total employment in NAICS sector 523 (securities, commodity contracts, and investments); and their c) ratio of sector 523 employment to population (expert density). Also reported are the corresponding city/area and state, in addition to the number of IPOs (observations (obs.)) originating in (not close to) the corresponding county and for which data is available (404 counties are documented in the data to have headquartered an IPO, out of approximately 3,000 existing U.S. counties). Source: The Securities Data Company New Issues database, the 2005 U.S. Census and the County Business Patterns database of the U.S. Census Bureau.

Panel A: Population

\begin{tabular}{|c|c|c|c|c|c|c|c|}
\hline & County & City/Area & State & $\begin{array}{r}\text { Estimated } \\
\text { population }\end{array}$ & $\begin{array}{r}\text { Est. expert } \\
\text { employment }\end{array}$ & $\begin{array}{l}\text { Expert } \\
\text { density }\end{array}$ & Obs. \\
\hline 1 & Los Angeles County & Los Angeles & California & $9,900,000$ & 26,433 & $0.27 \%$ & 121 \\
\hline 2 & Cook County & Chicago & Illinois & $5,300,000$ & 45,614 & $0.86 \%$ & 99 \\
\hline 3 & Harris County & Houston & Texas & $3,700,000$ & 11,885 & $0.32 \%$ & 114 \\
\hline 4 & Maricopa County & Phoenix & Arizona & $3,600,000$ & 12,233 & $0.34 \%$ & 41 \\
\hline 5 & Orange County & Santa Ana & California & $3,000,000$ & 17,500 & $0.59 \%$ & 77 \\
\hline 6 & San Diego County & San Diego & California & $2,900,000$ & 7,578 & $0.26 \%$ & 93 \\
\hline 7 & Kings County & Brooklyn & New York & $2,500,000$ & 3,202 & $0.13 \%$ & 1 \\
\hline 8 & Dallas County & Dallas & Texas & $2,300,000$ & 10,942 & $0.47 \%$ & 79 \\
\hline 9 & Queens County & Queens & New York & $2,200,000$ & 788 & $0.04 \%$ & 4 \\
\hline 10 & San Bernardino C. & San Bernardino & California & $2,000,000$ & 750 & $0.04 \%$ & 2 \\
\hline 11 & Wayne County & Detroit & Michigan & $2,000,000$ & 1,508 & $0.08 \%$ & 12 \\
\hline 12 & Riverside County & Riverside & California & $1,900,000$ & 1,750 & $0.09 \%$ & 1 \\
\hline 13 & Broward County & Fort Lauderdale & Florida & $1,800,000$ & 3,750 & $0.21 \%$ & 25 \\
\hline 14 & King County & Seattle & Washington & $1,800,000$ & 6,796 & $0.38 \%$ & 58 \\
\hline 15 & Santa Clara County & San Jose & California & $1,700,000$ & 4,049 & $0.24 \%$ & 261 \\
\hline 46 & Shelby County & Memphis & Tennessee & 909,035 & 3,198 & $0.35 \%$ & 12 \\
\hline 47 & Honolulu County & Honolulu & Hawaii & 905,266 & 1,750 & $0.19 \%$ & 2 \\
\hline 48 & Fairfield County & Bridgeport & Connecticut & 902,775 & 15,764 & $1.75 \%$ & 47 \\
\hline 49 & Bergen County & Hackensack & New Jersey & 902,561 & 3,750 & $0.42 \%$ & 23 \\
\hline 50 & Travis County & Austin & Texas & 888,185 & 2,941 & $0.33 \%$ & 38 \\
\hline 51 & Fresno County & Fresno & California & 877,584 & 750 & $0.09 \%$ & 1 \\
\hline 52 & Hartford County & Hartford & Connecticut & 877,393 & 3,750 & $0.43 \%$ & 14 \\
\hline 53 & Marion County & Indianapolis & Indiana & 863,133 & 3,750 & $0.43 \%$ & 15 \\
\hline 54 & New Haven County & New Haven & Connecticut & 846,766 & 994 & $0.12 \%$ & 13 \\
\hline 55 & Prince George's C. & Seabrook & Maryland & 846,123 & 375 & $0.04 \%$ & 5 \\
\hline 400 & Union County & Sioux & South Dakota & 13,462 & 10 & $0.07 \%$ & 1 \\
\hline 401 & Barton County & Lamar & Missouri & 13,057 & 10 & $0.08 \%$ & 1 \\
\hline 402 & Essex County & Tappahannock & Virginia & 10,492 & 10 & $0.10 \%$ & 1 \\
\hline 403 & Cheyenne County & Sidney & Nebraska & 9,993 & 10 & $0.10 \%$ & 1 \\
\hline 404 & Howard County & Cresco & Iowa & 9,700 & 10 & $0.10 \%$ & 1 \\
\hline \multirow[t]{4}{*}{ Mean: } & All & & & 459,259 & 2,007 & $0.28 \%$ & 9 \\
\hline & No. 1-10 (urban) & & & $3,740,000$ & 13,693 & $0.33 \%$ & 63 \\
\hline & No. $11-50$ & & & $1,234,357$ & 8,262 & $0.63 \%$ & 34 \\
\hline & No. 51-400 (rural) & & & 279,001 & 970 & $0.24 \%$ & 4 \\
\hline
\end{tabular}


Panel B: Expert employment

\begin{tabular}{|c|c|c|c|c|c|c|c|}
\hline & County & City/Area & State & $\begin{array}{r}\text { Estimated } \\
\text { population }\end{array}$ & $\begin{array}{r}\text { Est. expert } \\
\text { employment }\end{array}$ & $\begin{array}{l}\text { Expert } \\
\text { density }\end{array}$ & Obs. \\
\hline 1 & New York County & New York & New York & $1,600,000$ & 158,280 & $9.93 \%$ & 174 \\
\hline 2 & Suffolk County & Boston & Massachusetts & 654,428 & 46,547 & $7.11 \%$ & 38 \\
\hline 3 & Cook County & Chicago & Illinois & $5,300,000$ & 45,614 & $0.86 \%$ & 99 \\
\hline 4 & Los Angeles C. & Los Angeles & California & $9,900,000$ & 26,433 & $0.27 \%$ & 122 \\
\hline 5 & San Francisco C. & San Francisco & California & 739,426 & 19,662 & $2.66 \%$ & 51 \\
\hline 6 & Orange County & Santa Ana & California & $3,000,000$ & 17,500 & $0.59 \%$ & 77 \\
\hline 7 & Hudson County & Jersey City & New Jersey & 603,521 & 17,480 & $2.90 \%$ & 9 \\
\hline 8 & Fairfield County & Bridgeport & Connecticut & 902,775 & 15,764 & $1.75 \%$ & 47 \\
\hline 9 & Hennepin County & Minneapolis & Minnesota & $1,100,000$ & 15,035 & $1.34 \%$ & 58 \\
\hline 10 & Chester County & West Chester & Pennsylvania & 474,027 & 13,921 & $2.94 \%$ & 28 \\
\hline 11 & Maricopa County & Phoenix & Arizona & $3,600,000$ & 12,233 & $0.34 \%$ & 41 \\
\hline 12 & Harris County & Houston & Texas & $3,700,000$ & 11,885 & $0.32 \%$ & 114 \\
\hline 13 & Dallas County & Dallas & Texas & $2,300,000$ & 10,942 & $0.47 \%$ & 79 \\
\hline 14 & Philadelphia C. & Philadelphia & Pennsylvania & $1,500,000$ & 10,438 & $0.71 \%$ & 11 \\
\hline 15 & San Diego County & San Diego & California & $2,900,000$ & 7,578 & $0.26 \%$ & 93 \\
\hline 46 & Baltimore County & Baltimore & Maryland & 786,113 & 3,750 & $0.48 \%$ & 9 \\
\hline 47 & Multnomah C. & Portland & Oregon & 672,906 & 3,750 & $0.56 \%$ & 8 \\
\hline 48 & Providence C. & Providence & Rhode Island & 639,653 & 3,750 & $0.59 \%$ & 5 \\
\hline 49 & Arapahoe County & Aurora & Colorado & 529,090 & 3,750 & $0.71 \%$ & 19 \\
\hline 50 & New Castle C. & Wilmington & Delaware & 523,008 & 3,750 & $0.72 \%$ & 20 \\
\hline 51 & Polk County & Des Moines & Iowa & 401,006 & 3,750 & $0.94 \%$ & 8 \\
\hline 52 & Sacramento C. & Sacramento & California & $1,400,000$ & 3,542 & $0.26 \%$ & 6 \\
\hline 53 & Bexar County & San Antonio & Texas & $1,500,000$ & 3,514 & $0.23 \%$ & 12 \\
\hline 54 & Mercer County & Trenton & New Jersey & 366,256 & 3,401 & $0.93 \%$ & 19 \\
\hline 55 & DuPage County & Wheaton & Illinois & 929,113 & 3,350 & $0.36 \%$ & 19 \\
\hline 400 & Union County & Sioux & South Dakota & 13,462 & 10 & $0.07 \%$ & 1 \\
\hline 401 & Warren County & Indianola & Iowa & 42,981 & 10 & $0.02 \%$ & 2 \\
\hline 402 & Winona County & Winona & Minnesota & 49,276 & 10 & $0.02 \%$ & 1 \\
\hline 403 & Winston County & Haleyville & Alabama & 24,498 & 10 & $0.04 \%$ & 1 \\
\hline 404 & Tishomingo C. & Iuka & Mississippi & 19,202 & 6 & $0.03 \%$ & 1 \\
\hline \multirow[t]{4}{*}{ Mean: } & All & & & 459,259 & 2,007 & $0.28 \%$ & 9 \\
\hline & No. 1-10 (urban) & & & $2,427,418$ & 37,624 & $3.03 \%$ & 70 \\
\hline & No. $11-50$ & & & $1,160,822$ & 5,596 & $0.59 \%$ & 36 \\
\hline & No. 51-400 (rural) & & & 325,934 & 595 & $0.16 \%$ & 4 \\
\hline
\end{tabular}


Panel C: Expert density

\begin{tabular}{|c|c|c|c|c|c|c|c|}
\hline & County & City/Area & State & $\begin{array}{r}\text { Estimated } \\
\text { population }\end{array}$ & $\begin{array}{r}\text { Est. expert } \\
\text { employment }\end{array}$ & $\begin{array}{l}\text { Expert } \\
\text { density }\end{array}$ & Obs. \\
\hline 1 & New York County & New York & New York & $1,600,000$ & 158,280 & $9.93 \%$ & 174 \\
\hline 2 & Suffolk County & Boston & Massachusetts & 654,428 & 46,547 & $7.11 \%$ & 38 \\
\hline 3 & Chester County & West Chester & Pennsylvania & 474,027 & 13,921 & $2.94 \%$ & 28 \\
\hline 4 & Hudson County & Jersey City & New Jersey & 603,521 & 17,480 & $2.90 \%$ & 9 \\
\hline 5 & San Francisco & San Francisco & California & 739,426 & 19,662 & $2.66 \%$ & 51 \\
\hline 6 & Fairfield County & Bridgeport & Connecticut & 902,775 & 15,764 & $1.75 \%$ & 47 \\
\hline 7 & St. Louis city & St. Louis & Missouri & 344,362 & 5,724 & $1.66 \%$ & 3 \\
\hline 8 & Richmond city & Richmond & Virginia & 193,777 & 3,101 & $1.60 \%$ & 4 \\
\hline 9 & Hennepin County & Minneapolis & Minnesota & $1,100,000$ & 15,035 & $1.34 \%$ & 58 \\
\hline 10 & Morris County & Morristown & New Jersey & 490,593 & 6,412 & $1.31 \%$ & 15 \\
\hline 11 & Sarpy County & Bellevue & Nebraska & 139,371 & 1,750 & $1.26 \%$ & 1 \\
\hline 12 & Jefferson County & Fairfield & Iowa & 15,972 & 186 & $1.16 \%$ & 1 \\
\hline 13 & Norfolk County & Norfolk & Massachusetts & 653,595 & 6,759 & $1.03 \%$ & 15 \\
\hline 14 & Denver County & Denver & Colorado & 557,917 & 5,437 & $0.97 \%$ & 38 \\
\hline 15 & Montgomery C. & Pottstown & Pennsylvania & 775,883 & 7,500 & $0.97 \%$ & 25 \\
\hline 46 & Middlesex County & Edison & New Jersey & 789,516 & 3,750 & $0.47 \%$ & 21 \\
\hline 47 & Dallas County & Dallas & Texas & $2,300,000$ & 10,942 & $0.47 \%$ & 79 \\
\hline 48 & Waukesha County & Waukesha & Wisconsin & 378,971 & 1,750 & $0.46 \%$ & 5 \\
\hline 49 & Marin County & Novato & California & 246,960 & 1,123 & $0.45 \%$ & 12 \\
\hline 50 & Davidson County & Nashville & Tennessee & 575,261 & 2,606 & $0.45 \%$ & 14 \\
\hline 51 & Washoe County & Reno & Nevada & 389,872 & 1,750 & $0.45 \%$ & 6 \\
\hline 52 & Marion County & Indianapolis & Indiana & 863,133 & 3,750 & $0.43 \%$ & 15 \\
\hline 53 & Hartford County & Hartford & Connecticut & 877,393 & 3,750 & $0.43 \%$ & 14 \\
\hline 54 & Bergen County & Hackensack & New Jersey & 902,561 & 3,750 & $0.42 \%$ & 23 \\
\hline 55 & Radford city & Radford & Virginia & 14,575 & 60 & $0.41 \%$ & 2 \\
\hline 400 & Franklin County & Greenfield & Massachusetts & 72,334 & 10 & $0.01 \%$ & 1 \\
\hline 401 & Shiawassee County & Owosso & Michigan & 72,945 & 10 & $0.01 \%$ & 2 \\
\hline 402 & Berkeley County & Goose Creek & South Carolina & 151,673 & 19 & $0.01 \%$ & 2 \\
\hline 403 & Boone County & Florence & Kentucky & 106,272 & 10 & $0.01 \%$ & 1 \\
\hline 404 & Randolph County & Asheboro & North Carolina & 138,367 & 10 & $0.01 \%$ & 1 \\
\hline \multirow[t]{4}{*}{ Mean: } & All & & & 459,259 & 2,007 & $0.28 \%$ & 9 \\
\hline & No. 1-10 (urban) & & & 710,291 & 30,193 & $3.32 \%$ & 43 \\
\hline & No. $11-50$ & & & 800,142 & 5,436 & $0.69 \%$ & 21 \\
\hline & No. 51-400 (rural) & & & 413,583 & 823 & $0.15 \%$ & 6 \\
\hline
\end{tabular}

